\title{
Optimization of the Start-up Time of a Variable Speed Pump-Turbine Unit in Pumping Mode
}

\author{
Y. Pannatier, B. Kawkabani, C. Nicolet, A. Schwery, J.-J. Simond
}

\begin{abstract}
This paper presents the start-up and synchronization procedures of large variable-speed pump-turbine units in pumping mode. These procedures applied to a doubly-fed induction motor-generator with three-level voltage source inverters VSI cascade in the rotor side, can be achieved without any supplementary equipment, for instance without an autotransformer connected to the rotor. The control strategy used in the start-up procedure and based on a stator flux oriented control is summarized as well as different steps in order to reach the minimal speed required for synchronization. An optimization of the start-up time can be achieved by a modification of the modulation type of the converters. Simulated results obtained for two variable-speed pump-turbine units of $340 \mathrm{MW}$ and $250 \mathrm{MW}$ are presented and discussed.
\end{abstract}

Index Terms-control systems, numerical simulation, induction motors, AC-DC power converters, pumps, turbines, pulse width modulation, torque, variable speed drives.

\section{NOMENCLATURE}

$\begin{array}{ll}d t & \text { Phase difference in s } \\ f_{s}, f_{r} & \text { Stator/rotor frequency in per unit } \\ i & \text { Current in per unit } \\ J & \text { Inertia in } \mathrm{kgm}^{2} \\ n & \text { Speed in per unit } \\ p & \text { Active power in per unit } \\ r_{s}, r_{r} & \text { Resistance of the stator/rotor in per unit } \\ s & \text { Laplace operator } \\ t_{e x t} & \text { Torque of the pump-turbine in per unit } \\ t_{e m} & \text { Electromagnetic torque in per unit } \\ T h_{r} & \text { Park rotor angle in rad } \\ u & \text { Voltage in per unit } \\ x_{s}, x_{r} & \text { Total reactance of the stator/rotor in per unit }\end{array}$

This work was supported by ALSTOM Power Hydro in Birr, Switzerland and in Grenoble, France, CTI, Swiss Federal Commission for Technology and Innovation, contract award No 8330 and the CCEM-CH, Swiss Competence Center Energy and Mobility.

Y. Pannatier is with HYDRO Exploitation SA, Rue des Creusets 41, CP 750, CH-1951 Sion, Switzerland, (e-mail : pay@hydro-exploitation.ch).

B. Kawkabani and J.-J. Simond are with the EPFL, Ecole Polytechnique Fédérale de Lausanne at the Electrical Machinery Laboratory, CH-1015 Lausanne, Switzerland (phone: +41 2169346 90, fax: +41 2169326 87, email: basile.kawkabani@epfl.ch, jean-jacques.simond@epfl.ch).

C. Nicolet is with Power Vision Engineering sàrl, $1 \mathrm{ch}$. Champs-Courbes, CH-1024 Ecublens, Switzerland (e-mail: christophe.nicolet@powervisioneng.ch).

A. Schwery is with ALSTOM Switzerland Ltd, 40 Zentralstrasse, CH-5242 Birr, Switzerland (e-mail: alexander.schwery@power.alstom.com).

$\begin{array}{ll}x_{h} & \text { Magnetizing reactance in per unit } \\ \omega & \text { Angular frequency in } \mathrm{rad} / \mathrm{s} \\ \psi & \text { flux in per unit }\end{array}$

\section{INTRODUCTION}

$\mathrm{R}$ enewable energy resources like wind farms and hydro electric power plants will play in the coming years a more important role in the future power grids. Due to the high volatility of wind power, electrical power networks particularly islanded ones, with high level of wind power penetration, may be subject to instabilities. Variable speed pump-turbine units can significantly increase the stability of electrical power networks, and thus overcome this problem [1]-[5].

Several variable speed power stations are planned in Europe for the next coming years. Goldisthal, the first pump storage power plant using doubly fed induction machines, is operating in Germany since 2003. The power station is equipped with two variable speed units of $265 \mathrm{MW}$ each $(333 \mathrm{rpm}$, speed range of $[+4 \% ;-10 \%])$. The rotor is fed by a cyclo converter. In the new power stations planned in Switzerland for 2015, the rotor is fed by a three-level voltage source inverter VSI.

The study, modeling and analysis of the behavior of variable speed pump-turbine units have been presented and published in several papers in the last decade [6]-[16]. Among the papers dedicated to the study of the dynamic behavior of variable speed pump-turbine units [6]-[10], some ones [6]-[8] are focused particularly on the modeling of the hydraulic system and others [3], [9], [10] present detailed models of the electrical system including the control systems, but with simplified models of the hydraulic one. These different studies consider simplified models for the electrical system and do not take into account the converters. The modeling, simulation and analysis of the dynamic behavior of a 2 x 320 MW variable-speed pump-turbine power plant, including a hydraulic system, electrical equipment with the three-level VSIs of the converters, rotating inertias and control systems have been presented in [17]. Morel et al. [18] present the selfstarting and synchronization of a variable speed unit using a double fed induction machine. A field-oriented control strategy is described with and without a sensor. The starting is done with an autotransformer connected to the rotor, with the short-circuited stator. Then, the autotransformer is disconnected for the synchronization of the unit. Boldea ([19], chapter 2) describes this same control strategy and presents the 
transient response of a $400 \mathrm{MW}$ unit [9] for generating and pumping operation at the power grid. The theoretical aspects related to the start-up and synchronization procedures for such large pump-turbine units have been presented in details [20]. The aim of this paper is to present the aspects related to the optimization of the start-up procedure in order to guarantee the different operation modes within a reasonable time and by using the only existing equipment used in normal operating modes (speed sensor and without use of any autotransformer connected to the rotor). Two variable-speed pump-turbine units of $340 \mathrm{MW}$ and $250 \mathrm{MW}$ have been considered for this study. It is shown that on the one hand, for both units, under specified conditions, the start-up and synchronization in pumping mode can be achieved successfully without any additional equipment. On the other hand, the modification of the modulation type of the converters during the start-up is necessary in the case of the variable-speed pump-turbine unit of $340 \mathrm{MW}$, otherwise the start-up cannot be achieved without additional equipment. It leads to a significant decrease of the start-up time (factor $>2$ ) for the variable-speed unit of 250 MW.

The paper is organized as follows: Section III presents the modeling of the power plant. The start-up procedure based on a stator flux oriented control [21], as well as the optimization of the start-up time is presented in Section IV. Section V defines the condition to fulfill for the synchronization of the group. Different simulation results related to both procedures are presented for the two studied power plants and discussed in Section VI. Finally, conclusions are given in Section VII.

\section{MODELING OF THE POWER PLANT}

The complete model of the power plant is presented in Fig. 1.

Starting without water in the runner, the pump-turbine is simply modelled by a resistive torque depending on the speed. This torque includes pump-turbine friction losses, ventilation losses, bearing losses and is equal to $2.8 \%$ of the pump rated torque at rated speed. The saturation effect of the magnetizing reactance of the induction machine is considered.

The complete model of the electrical system comprises a doubly-fed induction motor-generator, with three-level Voltage Source Inverters (VSI) cascade in the rotor side [16], [22].

The main parameters of the double-fed induction generator are presented in TABLE I for the first power plant, and in TABLE II for the second one. The equations relative to its modeling are expressed in per unit in the synchronous reference frame.

$$
\begin{aligned}
& \underline{u}_{s}=r_{s} \underline{i}_{s}+j f_{s} \underline{\psi}_{s}+\frac{1}{\omega_{n}} s \cdot \underline{\psi}_{s} \\
& \underline{u}_{r}=r_{r} \underline{i}_{r}+j f_{r} \underline{\psi}_{r}+\frac{1}{\omega_{n}} s \cdot \underline{\psi}_{r}
\end{aligned}
$$

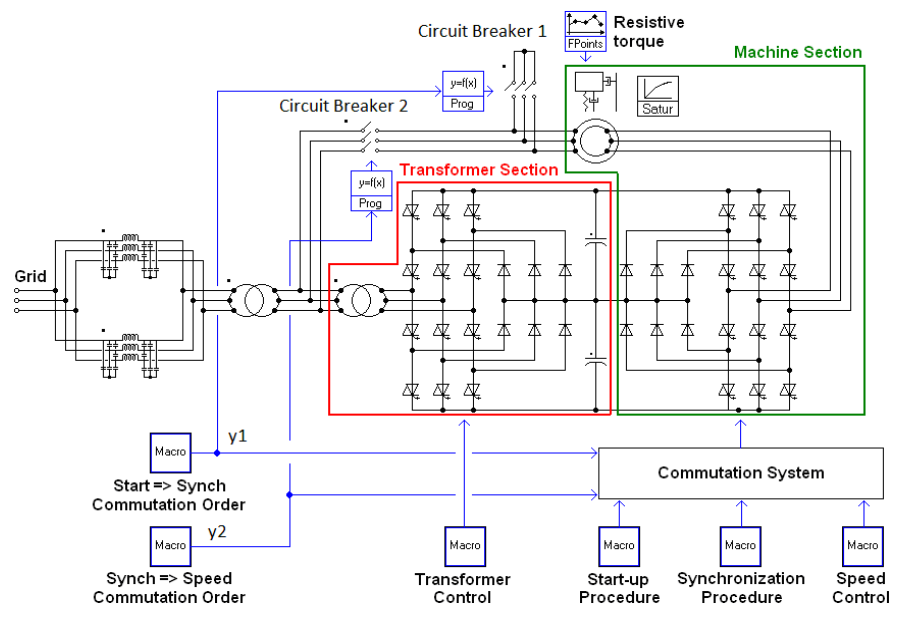

Fig.1. Complete model of the power plant

$$
\begin{aligned}
& \underline{\psi}_{s}=x_{s} \cdot \underline{i}_{s}+x_{h} \cdot \underline{i}_{r} \\
& \underline{\psi}_{r}=x_{r} \cdot \underline{i}_{r}+x_{h} \cdot \underline{i}_{s} \\
& s \cdot n=\frac{1}{T_{m}}\left(t_{e m}+t_{e x t}\right) \\
& t_{e m}=\operatorname{Im}\left(\underline{\psi}_{s}^{*} \cdot \underline{i}_{s}\right)=\frac{x_{h}}{x_{s}} \operatorname{Im}\left(\underline{\psi}_{s} \cdot \underline{i}_{r}^{*}\right)
\end{aligned}
$$

with

$T_{m}=\frac{J \cdot\left(N_{n} \cdot \pi / 30\right)^{2}}{S_{n}}$

The rated DC-link voltage of the three-level VSI rotor cascade is $U_{D C n}=6000 \mathrm{~V}$. In the case of a linear modulation in a three-phase inverter, the fundamental-frequency component in the output voltage varies linearly with the amplitude modulation ratio $m_{a}$ [23]. The peak value of the fundamental-frequency component in one of the inverter leg is given by:

$\hat{U}_{r_{-} p h}=m_{a} \cdot U_{D C n} / 2$ with $m_{a} \leq 1$

The electrical system can be divided into two sections, a transformer section and a machine one, see Fig. 1. The transformer section operates as a Static Var Compensator (SVC), its main role being to exchange reactive power with the grid. The reactive power and the capacitors voltage can be controlled by acting on the transformer primary side currents through the left-side converter.

The machine section is used to start up the unit, to synchronize it with the grid and finally to control the speed and the stator reactive power of the machine by acting on the rotor currents through the right-side converter [8], [17].

\section{START-UP PROCEDURE}

The machine is started up through the rotor cascade by short-circuiting the stator [20]. 
TABLE I

RATED VAlues Of The First Power-Plant

\begin{tabular}{|c|c|c|c|}
\hline Symbol & Quantity & Value & Unit \\
\hline$N_{n}$ & rated speed & 450 & rpm \\
\hline$S_{n}$ & rated apparent power & 380 & MVA \\
\hline$U_{n}$ & rated voltage & 18 & $\mathrm{kV}$ \\
\hline$f_{n}$ & rated frequency & 60 & $\mathrm{~Hz}$ \\
\hline $2 p$ & number of poles & 16 & - \\
\hline$\ddot{u}=\frac{N_{s} k_{w s}}{N_{r} k_{w r}}$ & transformation ratio & 0.589 & - \\
\hline$S_{\max }$ & maximum slip & 7 & $\%$ \\
\hline \multirow{2}{*}{$J_{\text {rotor }}$} & rotor inertia & 2661 & $\mathrm{tm}^{2}$ \\
\hline & coupling & Yy & \\
\hline$r_{s}$ & stator resistance & $1.74410^{-3}$ & $\mathrm{pu}$ \\
\hline$x_{\sigma s}$ & $\begin{array}{l}\text { stator leakage } \\
\text { reactance }\end{array}$ & 0.2603 & $\mathrm{pu}$ \\
\hline$x_{h}$ & magnetizing reactance & 4.1975 & $\mathrm{pu}$ \\
\hline$x_{\sigma r}{ }^{\prime}$ & rotor leakage reactance & 0.2720 & $\mathrm{pu}$ \\
\hline$r_{r}{ }^{\prime}$ & rotor resistance & $2.01410^{-3}$ & $\mathrm{pu}$ \\
\hline $\begin{array}{l}\text { Transformer } \\
\text { connected } \\
\text { to the grid }\end{array}$ & coupling & Yy0 & \\
\hline$S_{n}$ & rated apparent power & 380 & MVA \\
\hline$U_{n 1}$ & primary rated voltage & 230 & $\mathrm{kV}$ \\
\hline$U_{n 2}$ & $\begin{array}{l}\text { secondary rated } \\
\text { voltage }\end{array}$ & 18 & $\mathrm{kV}$ \\
\hline$x_{c c}$ & short-circuit reactance & 0.12 & $\mathrm{pu}$ \\
\hline$x_{h 1}$ & magnetizing reactance & 1000 & $\mathrm{pu}$ \\
\hline $\begin{array}{c}\text { Lines } \\
\text { connected } \\
\text { to the grid }\end{array}$ & equivalent reactance & 5.424 & $\Omega$ \\
\hline $\begin{array}{l}\text { Machine } \\
\text { section }\end{array}$ & $\begin{array}{l}\text { Switching frequency of } \\
\text { the converter }\end{array}$ & $1 ’ 140$ & $\mathrm{~Hz}$ \\
\hline $\begin{array}{c}\text { Transformer } \\
\text { section }\end{array}$ & $\begin{array}{l}\text { Switching frequency of } \\
\text { the converter }\end{array}$ & $2 ’ 160$ & $\mathrm{~Hz}$ \\
\hline
\end{tabular}

TABLE II

RAted VAlues Of The SECOND POWER-Plant

\begin{tabular}{clcc}
\hline \hline Symbol & \multicolumn{1}{c}{ Quantity } & Value & Unit \\
\hline$N_{n}$ & rated speed & 500 & $\mathrm{rpm}$ \\
$S_{n}$ & rated apparent power & 280 & $\mathrm{MVA}$ \\
$P_{n}$ & rated active power & 250 & $\mathrm{MW}$ \\
$U_{n}$ & rated voltage & 18 & $\mathrm{kV}$ \\
$f_{n}$ & rated frequency & 50 & $\mathrm{~Hz}$ \\
$2 p$ & number of poles & 12 & - \\
$S_{\max }$ & maximum slip & 6 & $\%$ \\
$\ddot{u}$ & transformation ratio & 0.566 & - \\
$J_{\text {rotor }}$ & rotor inertia & 1200 & $\mathrm{tm}^{2}$ \\
$J_{\text {turbine }}$ & pump-turbine inertia & 70 & $\mathrm{tm}^{2}$ \\
\hline \hline
\end{tabular}

\section{A. Control strategy}

The strategy considered for the start-up is based on a stator flux oriented control, so that it's possible to control the speed and the stator flux by acting on the rotor currents of the machine.

As the control strategy is oriented on the stator flux:

$\psi_{s q}=0 \quad \underline{\psi}_{s}=\psi_{s d}$

The control strategy is represented in Fig. 2. The stator flux and the speed can be controlled respectively by acting on the rotor currents in the $\mathrm{d}$ and $\mathrm{q}$ axes.

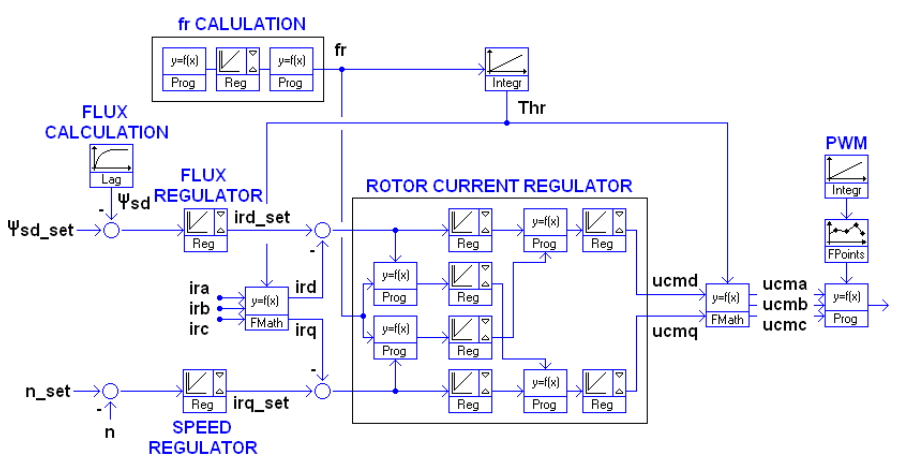

Fig.2. Start-up control strategy

In order to optimize the start-up procedure, the machine acceleration, and thus the electromagnetic torque, has to be maximized. The torque, produced by the flux in the direct-axis and the current in the quadrature axis, can be obtained from (6) and (8):

$t_{e m}=-\frac{x_{h}}{x_{s}} \cdot \psi_{s d} \cdot i_{r q}$

Consequently one has to impose the flux set point $\psi_{\text {sd_ } \_ \text {set }}$ and the rotor current set point in the quadrature axis $i_{r q \_s e t}$ so that the torque is maximal. Note that $i_{r q_{-} s e t}$ can be chosen by modifying the limit values of the speed regulator output, as this one is equal to its maximal value during all the start-up procedure. The three steps related to the start-up procedure are summarized in TABLE III [20].

\section{B. Maximal speed reachable at the end of the start-up procedure}

One can notice that the electromagnetic torque decreases with the rotor frequency while the absolute value of the external torque increases with this one. Consequently the maximal speed at the end of the start-up procedure $n_{\max \text { start }}$ is reached when both torques are equal, as represented in Fig. 3. The only way to increase $n_{\text {max start }}$ is then to increase the electromagnetic torque. From the expression of the electromagnetic torque given for Step 3 of the start-up, one can notice that the only modifiable parameter enabling to increase $t_{e m}$ is $u_{r_{-} \text {max }}$. 
TABLE III

Steps Related To The Start-Up Procedure

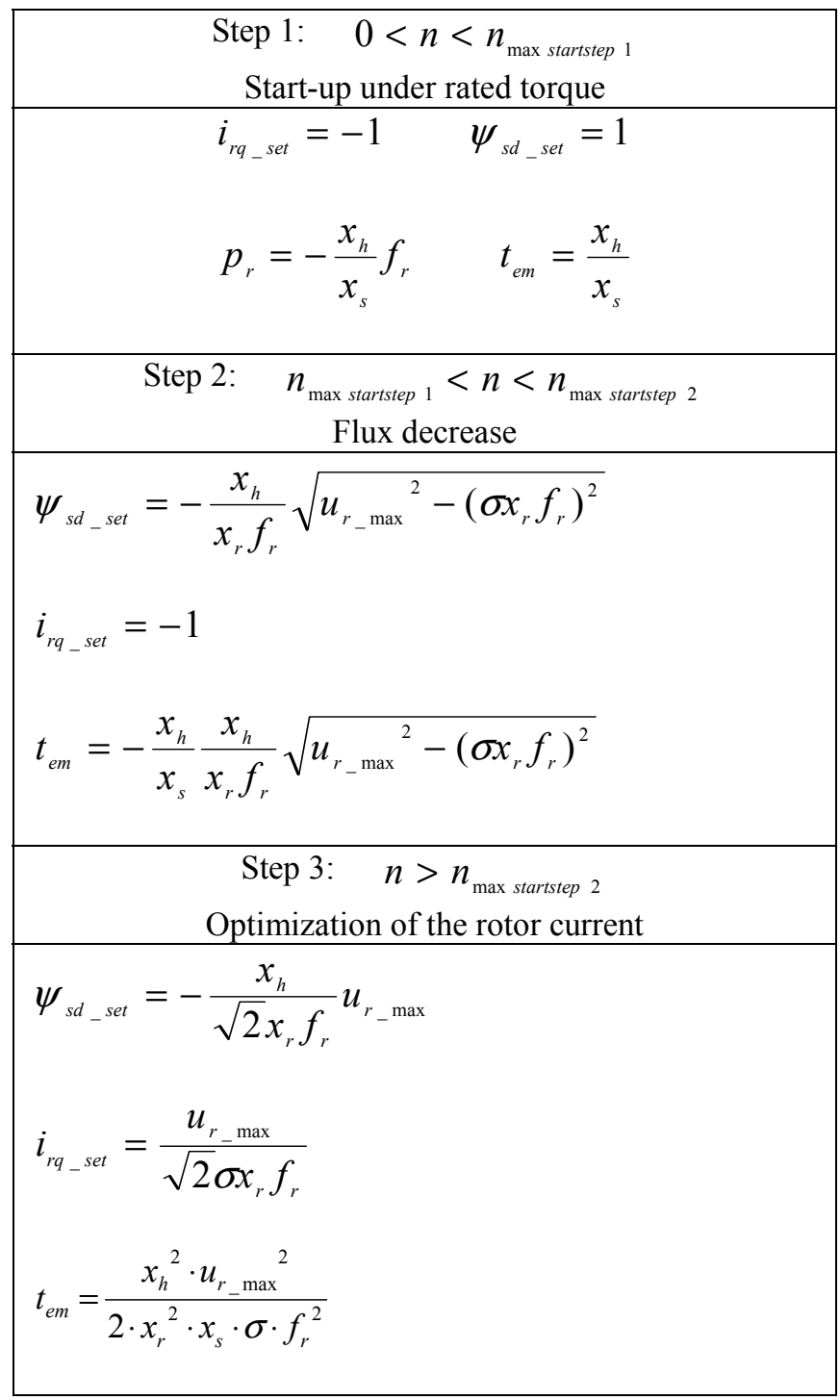

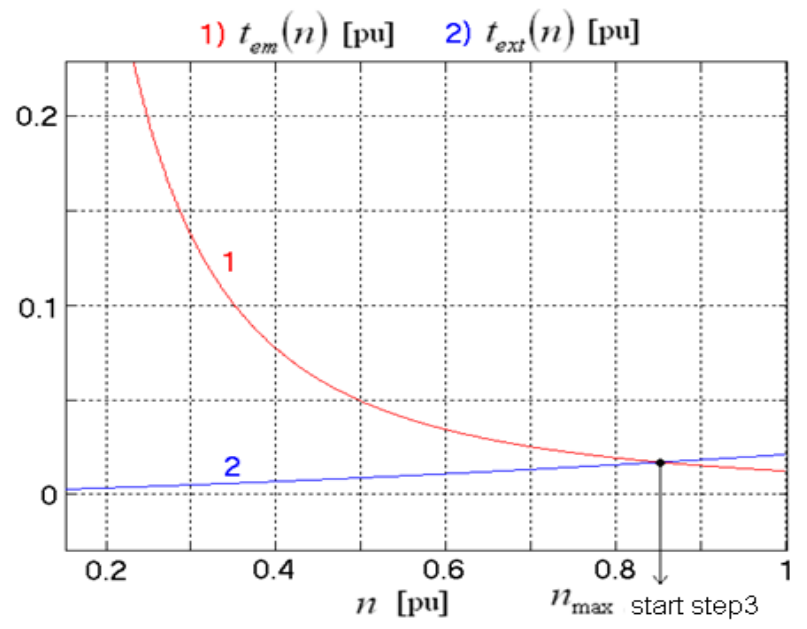

Fig.3. Electromagnetic and external torques.
This value depends on the DC voltage $U_{D C n}$ and on the modulation type. When considering a fixed modulation ratio, the relation (7) becomes

$$
\hat{U}_{r_{-} p h}=2 \cdot U_{D C n} / \pi
$$

This leads to an increase of $u_{r \text { max }}$ by a factor equal to $4 / \pi$. Nevertheless, the fixed modulation ratio does not allow the control of the amplitude of the rotor voltage but only the related frequency and phase. The idea is then to use this type of modulation only during the second and third steps of the start-up procedure, when the rotor voltage amplitude is equal to its maximal value and does not require to be controlled.

Consequently, a modulation type change at the end of the first step of the start-up procedure enables to increase the maximal rotor voltage and thus the maximal speed $n_{\max \_ \text {start }}$.

A disadvantage related to the use of the fixed modulation ratio is the introduction of supplementary harmonics. Indeed if the pulse width modulation generates harmonics only at the converter commutation frequency, the fixed modulation ratio introduces harmonics of order $6 k \pm 1$.

\section{SYNCHRONIZATION PROCEDURE}

Once the machine has reached a minimal speed required for synchronization, the stator terminals are opened and the stator voltage can be regulated in order to synchronize the machine with the grid. The synchronization is optimal if stator and grid voltages are equal in amplitude, frequency and phase. The control strategy used for the synchronization procedure is illustrated in Fig. 4 [20].

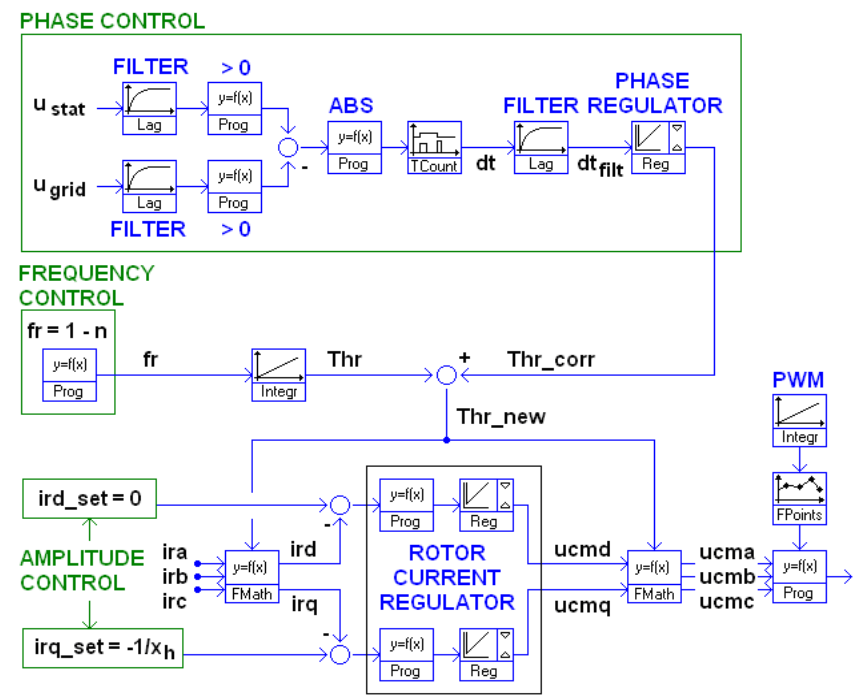

Fig.4. Synchronization control strategy

The minimal speed required for synchronization is given by:

$n_{\text {min_synch }}=1-f_{r_{-} \text {max_synch }_{-}}=1-\frac{1}{\omega_{n} T_{r}} \sqrt{\left(u_{r_{-} \max } \frac{\omega_{n} T_{r} x_{h}}{x_{r}}\right)^{2}-1}$

The synchronization of the group is only possible if the maximal speed reached at the end of the start-up procedure is greater than the minimal speed required for synchronization: 
$n_{\text {max_start }} \geq n_{\text {min_synch }}$

One can notice that during the synchronization procedure, the electromagnetic torque is equal to zero and the speed falls down. Consequently, at the end of the start-up procedure, the speed is equal to a value $n_{\text {synch_OK }}<n_{\text {min_synch }}$.

\section{SimULATION RESULtS}

\section{A. First variable speed pump-turbine unit (340 MW)}

For this unit, the condition for synchronization (Eq. 12) is not fulfilled, without additional equipment, for instance an autotransformer connected to the rotor. Thus, the modification of the modulation type is necessary in this case in order to achieve successfully the start-up and synchronization procedures. The speed and the electromagnetic torque during both procedures are represented in Fig. 5 and Fig. 6. The stator fluxes, rotor currents in the quadrature axis expressed in p.u are represented in Fig. 7 during the start-up procedure.

The rotor voltage during the start-up procedure is represented in Fig. 8. The grid and stator voltages expressed in p.u at the synchronization time (Fig. 9) confirm the effectiveness of the proposed approach.

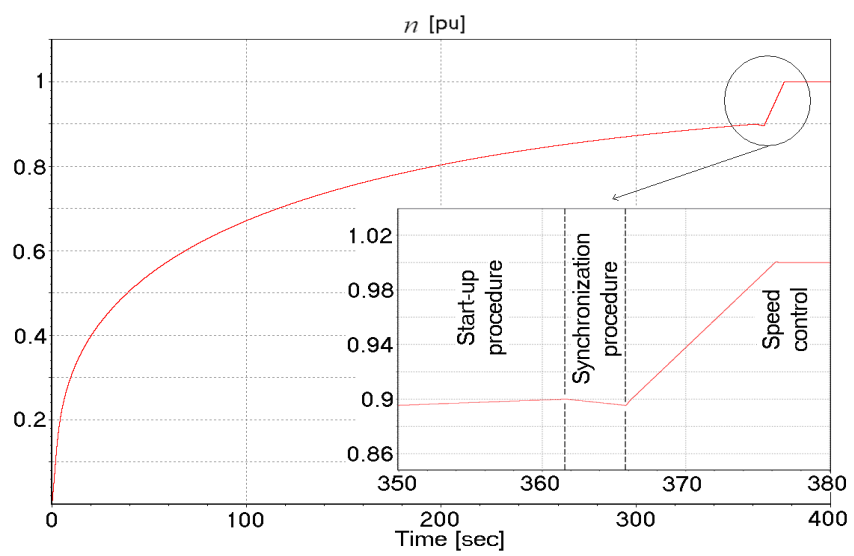

Fig.5. Speed in (p.u)

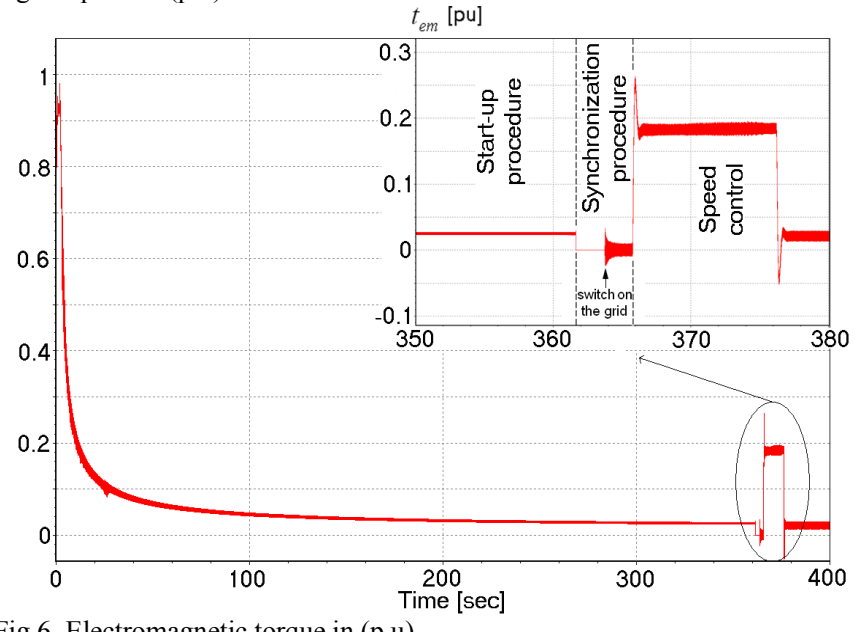

Fig.6. Electromagnetic torque in (p.u)

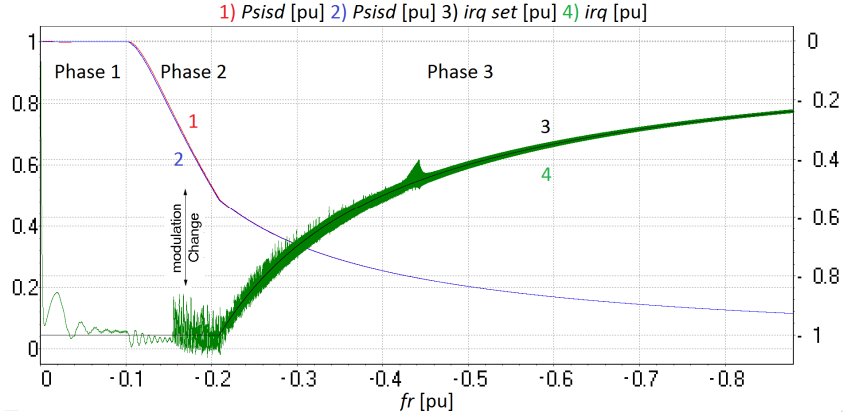

Fig.7. Stator fluxes, rotor currents in the quadrature axis in (p.u) during the start-up procedure

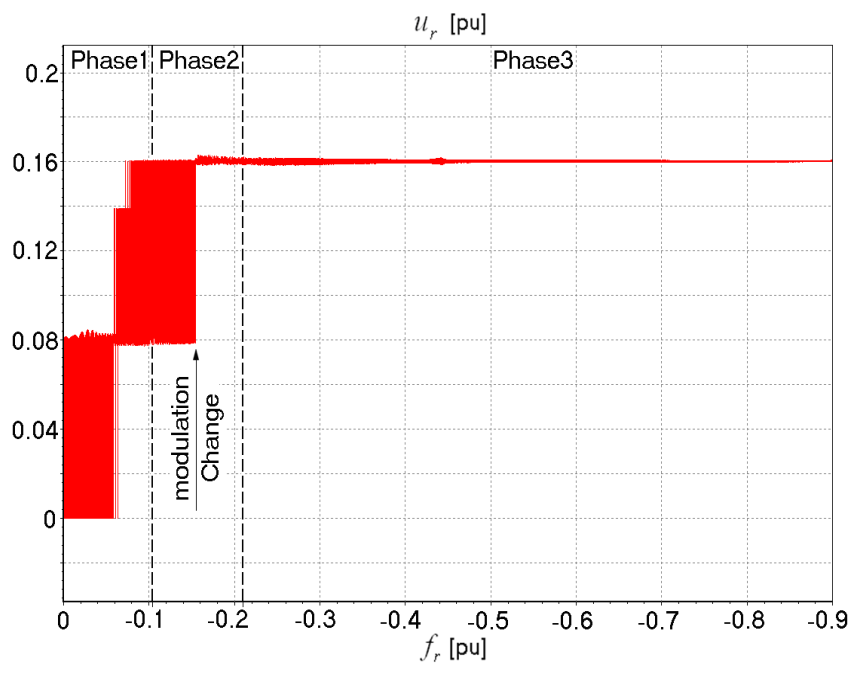

Fig.8. Rotor voltage in (p.u) during the start-up procedure

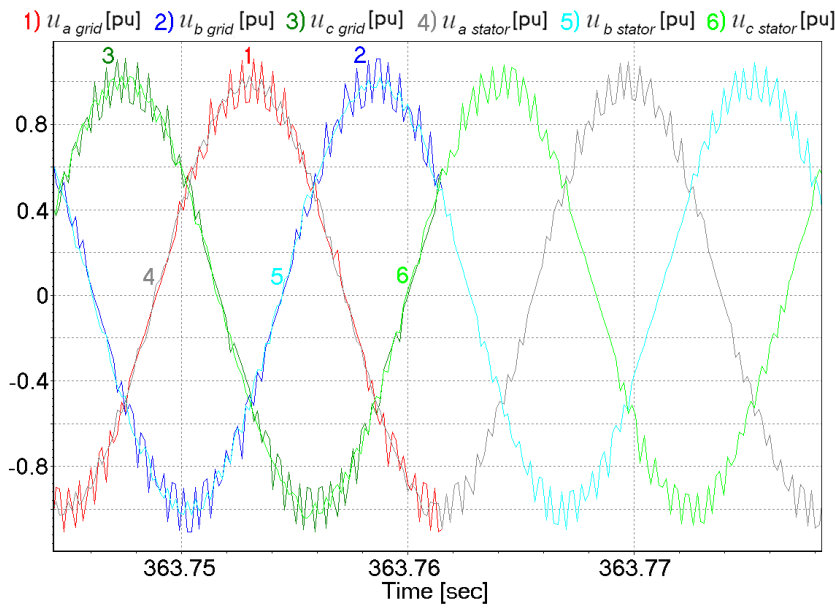

Fig.9. Grid and stator voltages in (pu) at synchronization time

\section{B. Second variable speed pump-turbine unit (250 MW)}

In this case, the condition for synchronization (Eq. 12) is fulfilled. Fig. 8 show that the modulation type modification enables to increase the maximal rotor voltage by a factor $4 / \pi$, which leads to an increase of the electromagnetic torque (Fig. 10). This greater torque allows an important reduction of the start-up time. One can notice that the start-up time is reduced significantly by a factor $>2$ when considering the modulation type modification, as shown in Fig. 11. 
The use of the fixed modulation ratio generates supplementary harmonics that can be observed in Fig.10. The generation of such harmonics didn't constitute a problem in this case, because they exist only during the start-up procedure, when the machine is not yet connected to the grid.

During the synchronization procedure, the fixed modulation ratio cannot be used because the control of the rotor voltage amplitude is required in order to control the stator voltage.

The global optimized procedure for both start-up and synchronization procedures of a variable-speed pump-turbine unit in pumping mode is summarized in TABLE IV. The values $\mathrm{y} 1$ and $\mathrm{y} 2$ are related to the outputs of the units (macro) shown in Fig. 1 and allowing the system to commute from a procedure to another one, when specific conditions are fulfilled.

TABLE IV

GLOBAL OpTIMIZED PROCEDURE

\begin{tabular}{clccc}
\hline \hline Speed [p.u] & Procedure & y1 & y2 & $\begin{array}{c}\text { Modulation } \\
\text { type }\end{array}$ \\
\hline 0 & Start-up & 0 & 0 & PWM \\
$n_{\text {max_start_step1 }}$ & Start-up & 0 & 0 & Fixed \\
$n_{\text {max_start_step } 2}$ & Start-up & 0 & 0 & Fixed \\
$n_{\text {min_synch }}$ & Synchronization & 1 & 0 & PWM \\
$n_{\text {synch_oK }}$ & Speed control & 1 & 1 & PWM \\
1 & Speed control & 1 & 1 & PWM \\
\hline \hline
\end{tabular}

\section{CONCLUSION}

The start-up and synchronization procedures of two variable-speed pump-turbine units of $340 \mathrm{MW}$ and $250 \mathrm{MW}$ in pumping mode are described. By fulfilling specified conditions, the start-up and synchronization of such units may be achieved without any additional equipment. The control strategy in the start-up procedure based on stator flux oriented control, and the conditions to fulfill in the synchronization procedure are summarized. The modification of the modulation type of the converters during the start-up procedure enables to achieve successfully the procedures for the variable-speed unit of $340 \mathrm{MW}$, and to reduce significantly the start-up time (factor $>2$ ) for the variable-speed unit of 250 MW. Simulated results obtained in different cases confirm the validity and the effectiveness of the proposed approach. Experiments on a 2-level VSI low power test bench of $2.2 \mathrm{~kW}$ are in progress in order to validate this approach.

\section{REFERENCES}

[1] H. K. Happoldt, O. J. Hartmann, E. Wiedemann, "The present state of pumped storage in Europe," IEEE Transactions on Power Apparatus and Systems, vol. 82, issue 68, pp. 618-631, October 1963.

[2] J.-J. Simond, A. Sapin, D. Schafer, "Expected benefits of adjustable speed pumped storage in the European network," Hydropower into the next century, pp. 579-585, Gmunden, Austria, 1999.

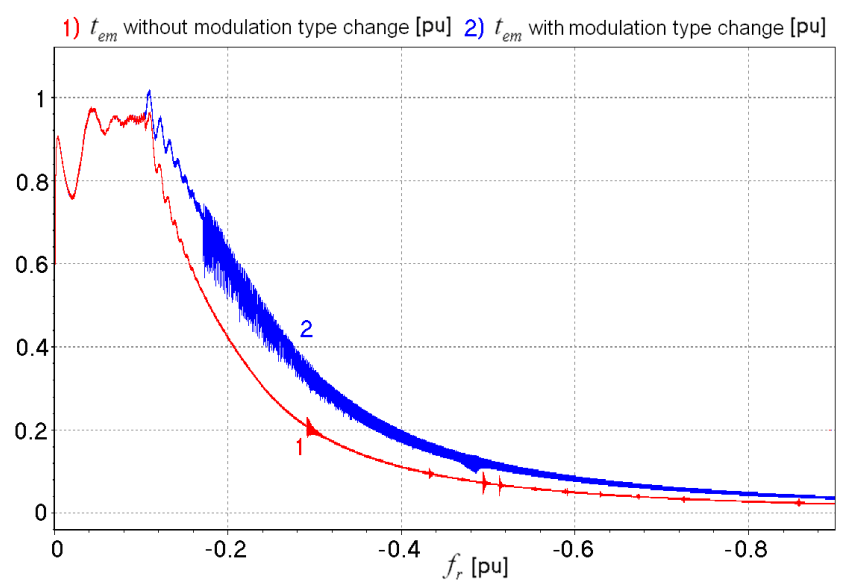

Fig.10. Electromagnetic torque in (p.u) during the start-up procedure with and without the modulation type modification

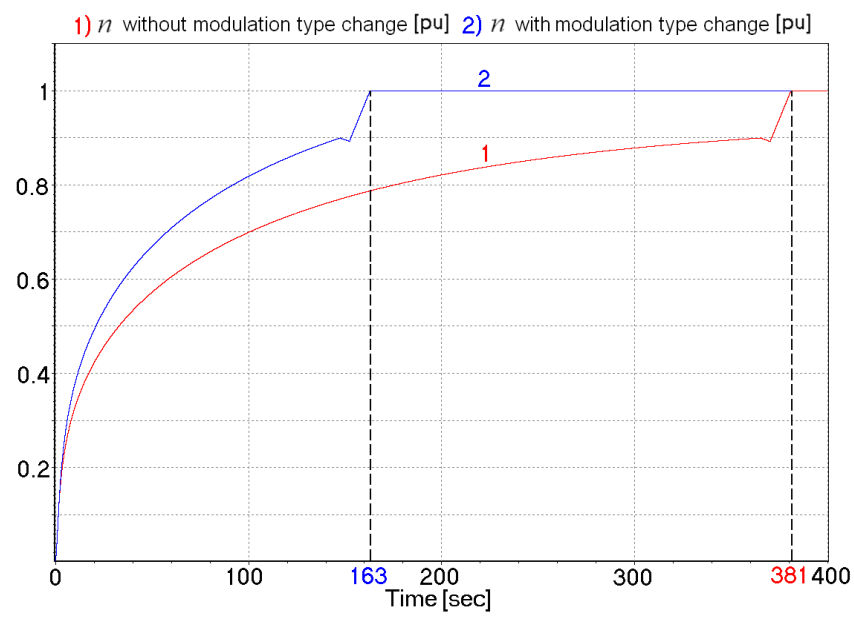

Fig. 11. Speed in (p.u) with and without the modulation type modification

[3] K. Grotenburg, F. Koch, I. Erlich, U. Bachmann, "Modeling and dynamic simulation of variable speed pump storage unit incorporated into the German Electric Power System," EPE 2001, Graz, Austria, 2001.

[4] A. Schwery, E. Fass, J.-M. Henry, W. Bach, A. Mirzaian, "Pump storage power plants, ALSTOM's long experience and technological innovation," Hydro 2005, Villach, Austria, 2005.

[5] Y. Pannatier, B. Kawkabani, G. Sari, J.-J. Simond, "Stability Studies of a Mixed Islanded Power Network with Varspeed Units using Simplified Models of the Converters", IEEE ECCE 2010, Atlanta, Georgia, September 2010.

[6] O. H. Souza Jr., N. Barbieri, A.H.M. Santos, "Study of hydraulic transients in hydropower plants through simulation of nonlinear model of penstock and hydraulic turbine model", IEEE Transactions on Power Systems, vol. 14, issue 4, pp. 1269-1272, 1999.

[7] H. Fang, L. Chen, N. Dlakavu, Z. Shen, "Basic modeling and simulation tool for analysis of hydraulic transients in hydroelectric power plants", IEEE Transactions on Energy Conversion, vol. 23, issue 3, pp. 834-841, September 2008.

[8] E. Kopf, S. Brausewetter, M. Giese, and F. Moser, "Optimized control strategies for variable speed machines," in Proc. 22nd IAHR Symp. Hydraulic Mach. Syst., Stockholm, Sweden, Jun. 29 - Jul. 2, 2004, Paper A15-2, pp. 1-9.

[9] T. Kuwabara, A. Shibuya, H. Furuta, E. Kita, K. Mitsuhashi, "Design and dynamic response characteristics of $400 \mathrm{MW}$ adjustable speed pumped storage unit for Ohkawachi power station," IEEE Transactions on Energy Conversion, vol. 11, issue 2, pp. 376-384, June 1996.

[10] J.-K. Lung, Y. Lu, W.-L. Hung, W.-S. Kao, "Modeling and dynamic simulations of doubly fed adjustable-speed pumped storage units," IEEE Transactions on Energy Conversion, vol. 22, issue 2, pp. 250-258, June 2007. 
[11] A. Bocquel, J. Janning, "Analysis of a $300 \mathrm{MW}$ variable speed drive for pump-storage plant applications," European Conference on Power Electronics and Applications, pp. 1-10, 2005.

[12] J. Fraile-Ardanuy, J. R. Wilhelmi, J. J. Fraile-Mora, J. I. Pérez, "Variable-speed hydro generation: operational aspects and control," IEEE Transactions on Energy Conversion, vol. 21, issue 2, pp. 569-574, June 2006

[13] C. Nicolet, B. Greiveldinger, J.-J. Hérou, B. Kawkabani, Ph. Allenbach, J.-J. Simond, F. Avellan, "High-order modeling of hydraulic power plant in islanded power network," IEEE Transactions on Power Systems, vol. 22, issue 4, pp. 1870-1880, November 2007.

[14] E. Levi, "Multiphase electric machines for variable-speed applications," IEEE Transactions on Industrial Electronics, vol. 55, issue 5, pp. 18931909, May 2008.

[15] G. Iwanski, W. Koczara, "DFIG-based power generation system with UPS function for variable-speed applications," IEEE Transactions on Industrial Electronics, vol. 55, issue 8, pp. 3047-3054, August 2008.

[16] A. Hodder, J.-J. Simond, A. Schwery, "Double trouble," IEEE Industry Applications Magazine, vol. 14, issue 2, pp. 32-39, 2008.

[17] Y. Pannatier, B. Kawkabani, C. Nicolet, J.-J. Simond, A. Schwery, P. Allenbach, "Investigation of Control Strategies for Variable Speed Pump-Turbine Units by using a Simplified Model of the Converters," IEEE Transactions on Industrial Electronics, vol. 57, issue 9, pp. 30393049, 2010, Digital Object Identifier 10.1109/TIE.2009.2037101.

[18] L. Morel, H. Godfroid, A. Mirzaian, J. M. Kauffmann, "Double-fed induction machine: converter optimization and field oriented control without position sensor," IEE Proceedings-Electric Power Applications, vol. 145, issue 4, pp. 360-368. 1998, Digital Object Identifier 10.1049/ip-epa: 19981982

[19] I. Boldea, "Variable speed generators," CRC Press, Taylor \&Francis Edition, 2006.

[20] Y. Pannatier, B. Kawkabani, C. Nicolet, A. Schwery, J.-J. Simond, "Start-up and Synchronization of a Variable Speed Pump-Turbine Unit in Pumping Mode," ICEM 2010 - XIX International Conference on Electrical Machines, Rome, Italy, Sept 6-8, 2010.

[21] A. Schwery, B. Kawkabani, M. Tu Xuan, J.-J. Simond, "Vector control of an induction machine in a stator flux reference frame," Proceedings of International Conference on Electrical Machines (ICEM'98), Istanbul (Turkey), September 1998, pp. 2001-2006. Available: http://lme.epfl.ch/page35076.html

[22] A. Hodder, J.-J. Simond, A. Schwery, "Unbalanced DC-link voltage regulation in a back-to-back 3-level PWM converter for a double-fed induction motor-generator," 2005 IEE Proceedings: Electric Power Applications 152 (6), pp. 1477-1481, 2005.

[23] P. N. Mohan, T. M. Undeland, W. P. Riobbins, "Power electronics converters, applications, and design," Wiley edition, 2007.

[24] R. C. Portillo, M. M. Prats, J. I. León, J. A. Sánchez, J. M. Carrasco, E. Galván, L. G. Franquelo, "Modeling strategy for back-to-back threelevel converters applied to high-power wind turbines", IEEE Transactions on Industrial Electronics, vol. 53, issue 5, pp. 1483-1491, October 2006.

[25] M. Blödt, D. Bonacci, J. Regnier, M. Chabert, J. Faucher, "On-line monitoring of mechanical faults in variable-speed induction motor drives using the Wigner distribution", IEEE Transactions on Industrial Electronics, vol. 55, issue 2, pp. 522-533, February 2008.

[26] G. O. Cimuca, C. Saudemont, B. Robyns, M. M. Radulescu, "Control and performance evaluation of a flywheel energy-storage system associated to a variable-speed wind generator", IEEE Transactions on Industrial Electronics, vol. 53, issue 4, pp. 1074-1085, August 2006.

[27] P. D. Brown, J. A. Peças Lopes, M. A. Matos, "Optimization of pumped storage capacity in an isolated power system with large renewable penetration", IEEE Transactions on Power Systems, vol. 23, issue 2, pp. 523-531, May 2008.

[28] B. Kawkabani, S. Duruz, A. Hodder, S. Robert, J.-J. Simond, "Benchmark test of a variable speed unit for teaching purposes", ICEM 2008, XVIII International Conference on Electrical Machines, Vilamoura, Portugal, September 2008

Yves Pannatier graduated from the EPFL and received his Master degree in Electrical Engineering in 2007. He obtained his PhD in 2010 from the same institutiom at the Electrical Machinery Laboratory of the EPFL. His main field of interest is the simulation of variable speed units in transient operation.

Basile Kawkabani (M'00-SM'11) received his master degree in 1978 from SUPELEC, Ecole Supérieure d'Electricité in Paris France, and his PhD degree in 1984 in Electrical Engineering from the Swiss Federal Institute of Technology in Lausanne (EPFL). From 1992 to 2010, he was lecturer and research associate at the EPFL Electrical Machinery Laboratory. He is currently a senior scientist in STI Scientists Group (Electrical Machinery EPFL), and senior member of the IEEE. His interests include modeling of power systems, power system stability and control.

Christophe Nicolet (M'08) graduated from the Ecole Polytechnique Fédérale de Lausanne, EPFL, in Switzerland, and received his Master degree in Mechanical Engineering in 2001. He obtained his PhD in 2007 from the same institution in the Laboratory for Hydraulic Machines. Since, he is managing director and principal consultant of Power Vision Engineering Sàrl in Ecublens, Switzerland. He is also lecturer at EPFL in the field of "Flow Transients in systems".

Alexander Schwery (M'04) holds a Phd degree in Electrical Engineering from the Swiss Federal Institute of Technology (EPFL 1999) in Lausanne. He joined ALSTOM (Switzerland) Ltd in 1999 where his main fields of application are the use and development of different simulation and calculation tools for salient pole generators. He is currently head of the electrical group in the Hydro Generator Technology Center.

Jean-Jacques Simond (M'00) graduated in Electrical Engineering in 1967 and got his doctoral degree in 1976 from EPFL, the Swiss Federal Institute of Technology in Lausanne. Till 1990 he was working for BBC / ABB first as R\&D engineer and later as head of the technical department for Hydro- and Diesel-generators. He was director of the Electrical Machinery Laboratory of the EPFL till 2011. Professor Emeritus from EPFL, he is also consultant for international electrical machines manufacturers and utilities. 